\title{
Psoriasiform papules, condyloma lata, lung nodules and hepatitis: the enormous variability of secondary syphilis manifestations
}

\author{
Diana Maria Monteiro Freitas, ${ }^{1}$ Alexandra Azevedo, ${ }^{2}$ Guiomar Pinheiro, ${ }^{1}$ Rosa Ribeiro ${ }^{3}$
}

${ }^{1}$ Hospital Geral de Santo António, Porto, Portugal ${ }^{2}$ Serviço de Dermatologia, Hospital Santo António, Porto, Portugal

${ }^{3}$ Internal Medicine Department, Centro Hospitalar Porto, Porto, Portugal

\section{Correspondence to}

Dr Diana Maria Monteiro

Freitas,

di.monteiro.freitas@gmail.com

Accepted 19 April 2017

\section{CrossMark}

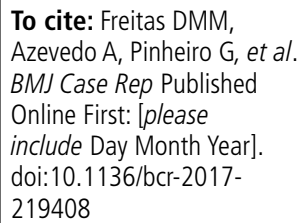

\section{DESCRIPTION}

A 44-year-old man, married, consulted his general practitioner with a 5-day history of fever, myalgia, headache and dry cough. Physical examination demonstrated wheezes in lung auscultation and liver function tests revealed cholestatic hepatitis with no increase in inflammatory markers; abdominal ultrasound was normal and thorax tomography showed small areas of subpleural consolidation (figure 1) and infracentimetric mediastinal lymph nodes suggestive of infection. A hepatotropic viral infection was presumed and he was treated symptomatically with no improvement. He was admitted to the hospital 2 weeks later presenting with perianal condylomata lata and psoriasiform papules affecting the trunk, genitalia, palms and soles (figure 2). Serological markers of hepatitis A, B and C and HIVs were negative and alpha 1-antitrypsin deficiency, autoimmunity and iron or copper overload were excluded. Both serum venereal disease research laboratory (VDRL) and treponemic tests were positive, the former with a titre of $1: 128$, and dark-field microscopy demonstrated Treponema pallidum in skin lesions. The diagnosis of secondary syphilis was established and T pallidum polypeptide antigens were detected in bronchoalveolar lavage using molecular biology techniques, which confirmed lung involvement. He was treated intramuscularly with a single dose of 2.4 million units IM of benzathine penicillin G. Control examination 1 month later showed a complete regression of symptoms and both skin

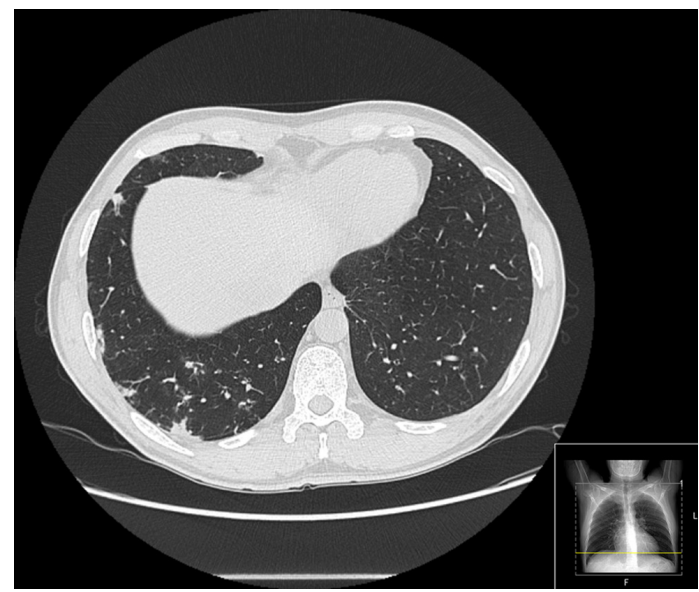

Figure 1 Thorax CT scan demonstrating small areas of subpleural consolidation.

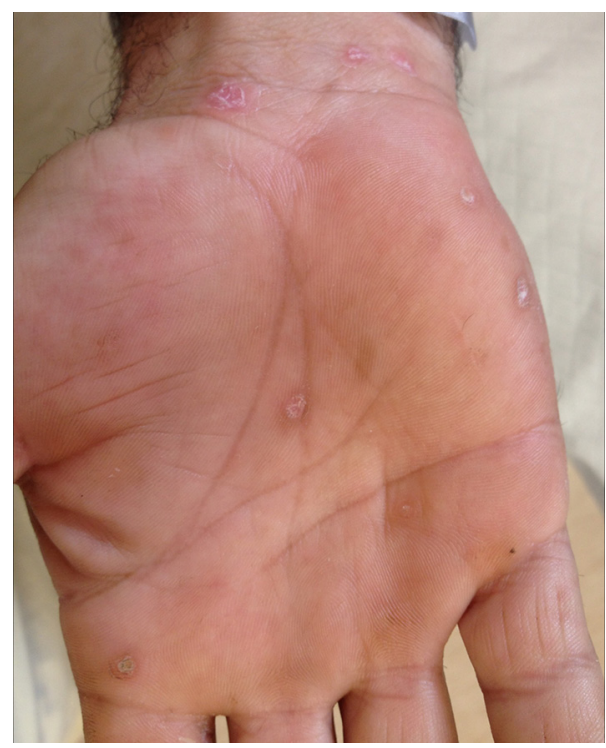

Figure 2 Palmar psoriasiform papules.

and lung lesions, as well as liver function normalisation, making the diagnosis of syphilitic hepatitis most likely. He would end up assuming swinging practice and his sexual partners were subsequenly tested and treated accordingly. VDRL titre fell to $1: 4$ within 12 months.

\section{Learning points}

- Secondary syphilis is a systemic disease that can affect most organs and tissues of the human body; due to the wide ranging variability in clinical presentation, this disease has earned the label 'the great imitator'. ${ }^{1}$

- With an increasing incidence during the past years, ${ }^{2}$ diagnosis is often missed or delayed, as the absence of classical features of the disease (such as the secondary syphilis orogenital lesion rash) and increasing number of unusual clinical presentations have been reported.

- A high level of suspicion is required for prompt recognition and management of this easily diagnosed and treatable condition, with therapeutic inertia being highly prejudiciable to the patient.

Contributors All the authors (DMMF, AA, GP and RR) gathered and wrote together this case report description. DMMF was the only responsible for bibliographic research and writing the conclusion for this manuscript. The corresponding author takes full responsibility for the overall content. 


\section{Images in...}

\section{Competing interests None declared.}

\section{Patient consent Obtained.}

Provenance and peer review Not commissioned; externally peer reviewed.

(C) BMJ Publishing Group Ltd (unless otherwise stated in the text of the article) 2017. All rights reserved. No commercial use is permitted unless otherwise expressly granted.

\section{REFERENCES}

1 Bittencourt MJ, Brito AC, Nascimento BA, et al. A case of secondary syphilis mimicking palmoplantar psoriasis in HIV infected patient. An Bras Dermatol 2015;90(3 Suppl 1):216-9.

2 David G, Perpoint T, Boibieux A, et al. Secondary pulmonary syphilis: report of a likely case and literature review. Clin Infect Dis 2006;42:e11-e15.

3 Song - Dan, Kim JH. Unusual presentation of Secondary Syphilis in Korea: 20102014 review. Korean J Urgent Tract Infect Inlamm 2015;10:19-24.

Copyright 2017 BMJ Publishing Group. All rights reserved. For permission to reuse any of this content visit

http://group.bmj.com/group/rights-licensing/permissions.

BMJ Case Report Fellows may re-use this article for personal use and teaching without any further permission.

Become a Fellow of BMJ Case Reports today and you can:

- Submit as many cases as you like

- Enjoy fast sympathetic peer review and rapid publication of accepted articles

- Access all the published articles

Re-use any of the published material for personal use and teaching without further permission

For information on Institutional Fellowships contact consortiasales@bmjgroup.com

Visit casereports.bmj.com for more articles like this and to become a Fellow 